\title{
DISTRIBUSI SIFAT KIMIA GAMBUT DI PERKEBUNAN SAWIT DAN HUBUNGANNYA DENGAN KEDALAMAN LAPISAN GAMBUT DAN JARAK DARI TANAH MINERAL BERBAHAN INDUK BATUAN ULTRABASA
}

\section{Selected Chemical Peat Properties Distribution in Oil Palm Plantation and Its Relationship with Depth Layer and Distance from Mineral Soil Derived From Ultrabasic Rocks}

\author{
Heru Bagus Pulunggono1)*, Moh. Zulfajrin') dan Arief Hartono') \\ 1) Departemen Ilmu Tanah dan Sumberdaya Lahan, Fakultas Pertanian, IPB University, Jl. Meranti Kampus IPB \\ Dramaga Bogor 16680 \\ 2) Program Studi Manajemen Sumberdaya Lahan, Departemen Ilmu Tanah dan Sumberdaya Lahan, Fakultas \\ Pertanian, IPB University, Jl. Meranti Kampus IPB Dramaga Bogor 16680
}

\begin{abstract}
Peatland at the research site utilized for oil palm plantation situated alongside with ultrabasic mineral soils. High Mg content in the soil has been reported to inhibit plant growth and distrupt nutrient absorption. Research is aimed to study the distribution of chemical properties of peat, that were $\mathrm{pH}$; Cation Exchange Capacity (CEC); the total (wet digestion) and exchangeable (extracted by amonium acetate $\mathrm{pH} 7$ ) contents of potassium $(\mathrm{K})$, calcium $(\mathrm{Ca})$ and magnesium $(\mathrm{Mg})$ macronutrient and sodium ( $\mathrm{Na}$ ); the total (wet digestion) and exchangeable (extracted by DTPA) contents of iron (Fe), manganese (Mn), copper $(\mathrm{Cu})$ and Zink $(\mathrm{Zn})$ micronutrients and their relationship with peat depth and distance to ultrabasic mineral soil. The composite of $1.0 \mathrm{~kg}$ peat soil samples were collected from the depth of $0-30 \mathrm{~cm}, 30-60 \mathrm{~cm}$ and $60-90 \mathrm{~cm}$ toposequently with the distance of 100, 200, 300, 400, 500 and $600 \mathrm{~m}$ from the ultrabasic mineral soil. The result of the study showed that pH value decreased significantly along with increasing peat depth and it tended to decrease with increasing distance from mineral soil. Contrastingly, CEC content increased significantly with increasing peat depth, however, tended to increase along with increasing distance from mineral soil. Based on the measurement of $\mathrm{Mg}$ and Fe, mineral soil nutrient affected peat to the distance of $600 \mathrm{~m}$ from its border. Na showed positive correlation with peat depth, indicating marine influence from mineral soil in subsurface. The great imbalancebetween $\mathrm{Mg}$ with other cations may disrupt root absorbtion and lead to K and Ca leaching from peat solum.
\end{abstract}

Keywords: Macro nutrients, peat, ultrabasic rocks

\section{ABSTRAK}

Lahan gambut di lokasi penelitian digunakan untuk perkebunan sawit berdampingan dengan tanah mineral berbahan induk ultrabasa berkadar Mg tinggi. Tanah berkadar Mg tinggi dapat mengakibatkan terhambatnya pertumbuhan tanaman dan gangguan serapan hara. Penelitian ini bertujuan mempelajari distribusi beberapa sifat kimia gambut seperti $\mathrm{pH}$; kapasitas tukar kation (KTK); kandungan total (pengabuan basah) dan dapat dipertukarkan (amonium asetat $1 \mathrm{~N}$ pH 7) dari hara makro kalium $(\mathrm{K})$, kalsium $(\mathrm{Ca})$, magnesium $(\mathrm{Mg})$ dan natrium $(\mathrm{Na})$; kandungan total (pengabuan basah) dan dapat dipertukarkan (terekstrak DTPA) dari hara mikro besi $(\mathrm{Fe})$, tembaga $(\mathrm{Cu})$, seng $(\mathrm{Zn})$ dalam gambut dan hubungannya dengan kedalaman lapisan gambut dan jarak terhadap tanah mineral berbahan induk batuan ultrabasa. Contoh gambut sekitar $1.0 \mathrm{~kg}$ diambil secara komposit dari setiap kedalaman gambut 0 - 30, 30 - 60 dan 60-90 cm pada transek toposekuen dari setiap jarak 100, 200, 300, 400, 500 dan $600 \mathrm{~m}$ dari perbatasan tanah mineral ultrabasa. Hasil penelitian menunjukkan nilai pH gambut menurun sangat nyata berdasarkan kedalaman lapisan gambut dan cenderung menurun dengan semakin jauh dari tanah mineral. Nilai KTK berfluktuasi dan cenderung meningkat sesuai peningkatan kedalaman lapisan gambut dan jarak dari tanah mineral. Berdasarkan hasil pengukuran $\mathrm{Mg}$ dan $\mathrm{Fe}$, hara yang berasal dari tanah mineral mempengaruhi gambut hingga jarak $600 \mathrm{~m}$ dari batas gambut. Na menunjukkan korelasi positif dengan kedalaman lapisan gambut yang mengindikasikan pengaruh marin pada tanah mineral bawah gambut. Ketimpangan yang besar antara $\mathrm{Mg}$ dengan kation lain dapat mengganggu penyerapan hara oleh akar tanaman dan memungkinkan pencucian $\mathrm{K}$ dan Ca keluar dari solum.

Kata kunci: Hara makro, gambut, batuan ultrabasa

\section{PENDAHULUAN}

Peningkatan kebutuhan industri minyak nabati dunia (USDA, 2019) dihadapkan pada berkurangnya luasan tanah mineral yang produktif di Indonesia (Sitorus et al., 2011) menyebabkan peluang ekstensifikasi perkebunan sawit mengarah ke kawasan berlahan gambut. Lahan gambut dikategorikan sebagai lahan suboptimal (Mulyani dan Sarwani, 2013), namun berpotensi untuk dikembangkan bagi usaha pertanian dan perkebunan (Mulyani et al., 2016). Luas lahan gambut di Indonesia menurut Ritung et al. (2019) sebesar 13.4 juta hektar yang sebagian besar tersebar di Pulau Sumatera, Kalimantan, dan Papua serta sebagian kecil di Pulau Sulawesi. 
Berdasarkan Kepmen LHK Nomor 130 Tahun 2017, Ritung et al. (2019) dan hasil pengamatan lapangan, lahan gambut di Pulau Sulawesi ditemukan antara lain di sekitar Sungai Laa dan Sungai Petasia, berada di empat desa: Desa Bungintimbe, Towara, Molino, dan Polewali di Kabupaten Morowali Utara. Aspek kimia dan kesuburan pada gambut tersebut, yang digunakan untuk perkebunan sawit, perlu diteliti lebih lanjut karena terbentuk di atas tanah mineral hasil pelapukan batuan ultrabasa berkadar $\mathrm{Mg}$ tinggi, namun mempunyai kandungan $\mathrm{K}$ dan $\mathrm{Ca}$ yang rendah (Kadarusman et al., 2004; Fu et al., 2014).

Tanah gambut yang mengandung $\mathrm{Mg}$ dalam kadar tinggi berpotensi menghambat pertumbuhan dan perkembangan tanaman kelapa sawit. Kandungan $\mathrm{Mg}$ yang tinggi dalam tanah dapat memicu antagonisme ion $\mathrm{Mg}^{2+}$ dengan kation lainnya yang berkadar relatif rendah seperti $\mathrm{K}$ dan Ca pada komplek jerapan koloid organik tanah dan zona perakaran tanaman (Jenny, 1966; Lund, 1970). Implikasi logis yang dapat terjadi adalah potensi pencucian $\mathrm{K}$ dan $\mathrm{Ca}$ dari dalam solum, inefisiensi penggunaan pupuk dan tidak tersedianya unsur hara bagi tanaman dalam jangka panjang.

Kajian mengenai distribusi pH, Kapasitas Tukar Kation (KTK), kandungan hara makro dan mikro dalam gambut di lokasi penelitian belum banyak dilaksanakan. Oleh karena itu, penelitian ini dilakukan untuk mempelajari distribusi pH; KTK; kandungan hara makro K, Ca dan Mg total dan dapat dipertukarkan; $\mathrm{Na}$ dapat dipertukarkan; dan hara mikro $\mathrm{Fe}, \mathrm{Cu}$, dan $\mathrm{Zn}$ total dan dapat dipertukarkan pada beberapa lapisan kedalaman gambut dan jarak dari tanah mineral berbahan induk batuan ultrabasa

\section{BAHAN DAN METODE}

Penelitian dilakukan pada bulan Maret 2018 Januari 2019. Pengambilan contoh bahan tanah mineral dan gambut dilaksanakan di perkebunan sawit Desa Molino, Kecamatan Petasia Timur, Morowali Utara, Sulawesi
Tengah. Lokasi penelitian ditampilkan pada Gambar 1. Analisis sifat kimia tanah dilakukan di Laboratorium Kimia dan Kesuburan Tanah, Departemen Ilmu Tanah dan Sumberdaya Lahan, Fakultas Pertanian, Institut Pertanian Bogor.

Contoh bahan gambut diambil komposit pada setiap kedalaman lapisan gambut 0-30, 30-60, dan 60-90 $\mathrm{cm}$ pada transek toposekuen dari setiap jarak 100, 200, 300, 400, 500 dan $600 \mathrm{~m}$ dari perbatasan tanah mineral ultrabasa. Contoh bahan tanah mineral ultrabasa diambil pada kedalaman $0-30 \mathrm{~cm}$ dari sekitar areal gambut untuk analisis kadar $\mathrm{Fe}, \mathrm{Cu}$ dan $\mathrm{Zn}$ total. Contoh bahan gambut dan tanah mineral masing-masing diambil sekitar $1.0 \mathrm{~kg}$. Contoh tanah dikering-udarakan kemudian dihaluskan. Pengukuran kadar total unsur $\mathrm{Fe}, \mathrm{Zn}$, dan $\mathrm{Cu}$ menggunakan metode pengabuan basah dengan pengekstrak $\mathrm{HNO}_{3}$ dan $\mathrm{HClO}_{4}$ (Miller, 1998). Analisis contoh gambut dalam keadaan basah (sesuai dengan kondisi lapangan) meliputi: (i) beberapa sifat kimia gambut yang terdiri atas pengukuran $\mathrm{pH} \mathrm{H}_{2} \mathrm{O}$ (1:5) menggunakan $\mathrm{pH}$ meter; KTK, unsur hara makro $\mathrm{K}, \mathrm{Ca}, \mathrm{Mg}$, dan unsur $\mathrm{Na}$, dengan pengekstrak amonium asetat (Schollenberger dan Simon, 1945); dan unsur hara mikro $\mathrm{Fe}, \mathrm{Cu}, \mathrm{Zn}$ dengan pengekstrak DTPA (Lindsay dan Norvell, 1978). Pengukuran unsur hara makro $\mathrm{Ca}, \mathrm{Mg}$,dan unsur hara mikro menggunakan atomic absorption spectrophotometer sedangkan pengukuran $\mathrm{K}$ dan $\mathrm{Na}$ menggunakan flame emission spectrophotometer.

Pengolahan data dilakukan dengan menggunakan uji korelasi Spearman Rank (Spearman, 1904; Spearman, 1906) antara pH, KTK, unsur hara makro, Na dan mikro dengan kedalaman lapisan gambut dan jarak dari tanah mineral ultrabasa. Analisis dilanjutkan dengan melakukan uji lanjut pada selang kepercayaan $95 \%$ dan $99 \%$. Selain itu dilakukan pula analysis of variance (ANOVA) yang dilanjutkan dengan uji Tukey/beda nyata jujur (BNJ) pada selang kepercayaan $95 \%$. Analisis menggunakan program komputer Microsoft Excel dan Minitab versi 16.2.1.

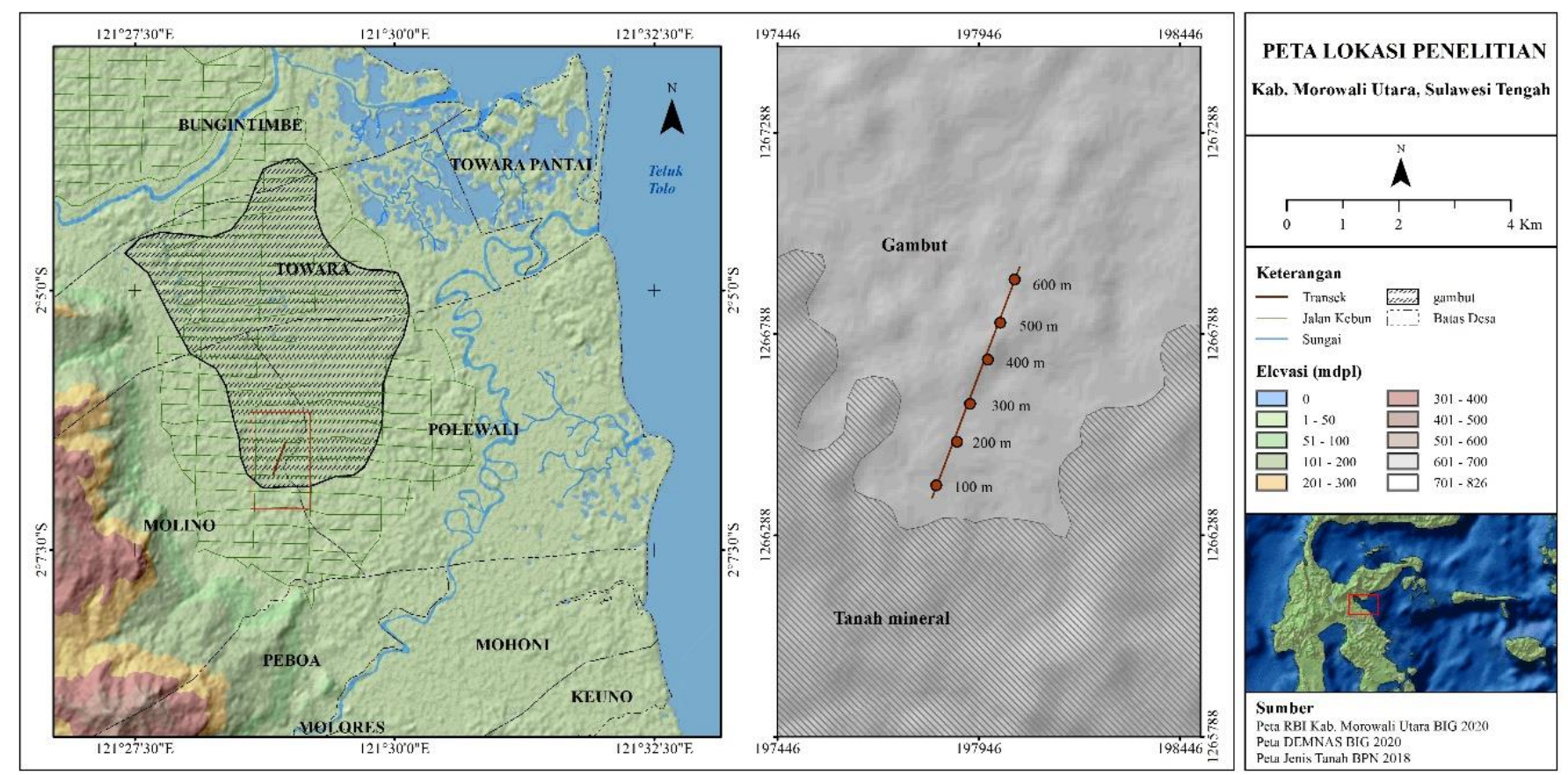

Gambar 1. Peta lokasi penelitian 


\section{HASIL DAN PEMBAHASAN}

\section{Distribusi pH dan KTK Gambut serta Hubungannya dengan Kedalaman Lapisan Gambut dan Jarak dari Tanah Mineral Ultrabasa}

Berdasarkan hasil analisis $\mathrm{pH}$ dan KTK yang disajikan dalam Tabel 1, pH gambut menurun sangat nyata berdasarkan kedalaman lapisan gambut. Proses dekomposisi bahan organik dalam gambut berkontribusi sebagai bahan penyumbang ion $\mathrm{H}^{+}$yang dapat menurunkan pH gambut (Clymo, 1964; Yonebayashi et al., 1994). Pada lahan perkebunan sawit yang diteliti, telah dibangun saluran drainase yang berfungsi dengan baik. Riwandi (2001) mengemukakan bahwa pencucian asam-asam organik akibat drainase secara intensif ke bawah permukaan menyebabkan terjadinya akumulasi asam-asam organik pada bagian bawah gambut, sehingga $\mathrm{pH}$ gambut menurun. Secara umum, tanah gambut pada bagian bawah mempunyai tingkat kematangan yang lebih rendah dari bagian atasnya. Bahan organik gambut yang belum matang dan relatif belum terurai, mengandung asam-asam organik dengan konsentrasi yang lebih tinggi sehingga nisbi masam (Noor et al., 2014). Peningkatan kadar air seiring dengan peningkatan kedalaman gambut menyebabkan peningkatan kuantitas bakteri fermentatif dan sulphur metabolizing bacteria sebagai dekomposer bahan organik secara anaerob (Clymo, 1964; Pester et al., 2012). Mikroorganisme tersebut menyekresikan sulfat, asetat dan asam-asam organik lainnya yang dapat menurunkan $\mathrm{pH}$ gambut (Fauque, 1995; Miyajima et al., 1997).

Tabel 1. Hasil analisis pH dan KTK gambut pada setiap kedalaman lapisan gambut dan jarak dari tanah mineral ultrabasa

\begin{tabular}{ccc}
\hline \multicolumn{1}{c}{ Faktor } & $\mathrm{pH} \mathrm{H}_{2} \mathrm{O} 1: 5$ & $\mathrm{KTK}$ \\
\hline Kedalaman $(\mathrm{cm})$ & & $\mathrm{cmol}^{(+)} \mathrm{kg}^{-1}$ tanah \\
\hline N kedalaman: 12 & & \\
$0-30$ & $4.88 \mathrm{a}$ & $113.81 \mathrm{ab}$ \\
$30-60$ & $4.29 \mathrm{~b}$ & $105.87 \mathrm{~b}$ \\
$60-90$ & $3.85 \mathrm{c}$ & $131.11 \mathrm{a}$ \\
Uji F & $* *$ & $* *$ \\
Korelasi & -0.61 & 0.38 \\
Uji t & $* *$ & $*$
\end{tabular}

\begin{tabular}{|c|c|c|}
\hline$\underline{\operatorname{Jarak}(\mathrm{m})}$ & & \\
\hline $\mathrm{N}$ jarak: 6 & & \\
\hline 100 & 4.25 & 124.16 \\
\hline 200 & 4.60 & 115.64 \\
\hline 300 & 4.48 & 103.07 \\
\hline 400 & 4.13 & 100.78 \\
\hline 500 & 4.60 & 128.39 \\
\hline 600 & 4.00 & 129.54 \\
\hline Uji F & tn & tn \\
\hline Korelasi & -0.12 & 0.14 \\
\hline Uji t & tn & tn \\
\hline Interaksi Kedalaman x Jarak & $* *$ & tn \\
\hline
\end{tabular}

Bila dikaitkan dengan jarak dari tanah mineral ultrabasa, $\mathrm{pH}$ gambut berfluktuasi dan cenderung menurun dengan semakin jauh dari tanah mineral. Namun, interaksi antara kedalaman lapisan gambut dan jarak dari tanah mineral ultrabasa memberikan pengaruh yang sangat nyata pada perubahan $\mathrm{pH}$ gambut.
Berdasarkan kriteria Tim Faperta IPB (2012), KTK pada daerah studi tergolong kelas sedang (100-160 cmol(+) $\mathrm{kg}^{-1}$ tanah). Nilai KTK yang tinggi pada gambut yang diteliti merupakan akibat dari dominasi gugus fungsi fenol, karboksil, amina, amida, dan lain-lain yang bersumber dari dekomposisi bahan organik (Sabiham, 2010). KTK gambut pada kedalaman $30-60 \mathrm{~cm}$ berbeda sangat nyata dengan KTK pada kedalaman $60-90 \mathrm{~cm}$. KTK gambut meningkat secara nyata sesuai dengan peningkatan kedalaman lapisan gambut. KTK gambut yang diteliti menunjukkan nilai yang tidak berbeda nyata berdasarkan jarak dari tanah mineral ultrabasa, namun cenderung meningkat dengan semakin jauh jarak dari tanah mineral. Hal tersebut kemungkinan disebabkan oleh adanya ameliorasi tanah mineral setiap tahun pada lapisan atas $(0$ $40 \mathrm{~cm}$ ) terutama pada jarak 100-400 $\mathrm{m}$ oleh pengelola kebun kelapa sawit yang bertujuan untuk menurunkan kadar asam organik dalam bahan gambut. Hal ini dilakukan sesuai dengan BMP (best management practice) pemanfaatan lahan gambut untuk perkebunan kelapa sawit.

\section{Kandungan Hara Makro K, Ca dan Mg serta Hara Benefisial Na Berdasarkan Kedalaman Lapisan Gambut dan Jarak dari Tanah Mineral Ultrabasa}

Kandungan hara $\mathrm{K}$, $\mathrm{Ca} \mathrm{Mg}$ serta $\mathrm{Na}$ dapat dipertukarkan dan total berdasarkan kedalaman gambut dan jarak dari tanah mineral ultrabasa disajikan pada Tabel 2. Berdasarkan kedalaman gambut, kandungan $\mathrm{K}, \mathrm{Ca}$ dan $\mathrm{Mg}$ berfluktuasi. Bila dikaitkan dengan jarak dari tanah mineral ultrabasa, kandungan $\mathrm{K}$ dan $\mathrm{Ca}$ secara umum sangat nyata menurun dengan semakin jauh dari batas tanah mineral tersebut; sedangkan kandungan $\mathrm{Mg}$ menunjukkan nilai yang fluktuatif dan berkorelasi tidak nyata.

Secara umum, gambut yang diteliti memiliki kandungan hara baik total maupun dapat dipertukarkan yang rendah seperti terlihat pada unsur $\mathrm{K}$ dapat dipertukarkan pada jarak 500 dan 600 meter dari tanah mineral ultrabasa (Tabel 2). Sabiham dan Furukawa (1986) menyatakan bahwa tumbuhan berkayu merupakan kontributor utama dari bahan organik penyusun tanah gambut daerah tropik. Hasil dekomposisi lignin sebagai fraksi dominan bahan kayu tanpa pengaruh eksternal membebaskan unsur hara dalam jumlah sedikit dicerminkan oleh kadar abu yang rendah (Page et al., 2004) atau tingkat loss on ignition lebih besar dari 90\% (Sabiham, 1988). Kandungan total kedua unsur tersebut menunjukkan kemiripan dengan hasil penelitian di gambut oligotrofik yang duduk pada formasi geologis batuan masam di Kalimantan (Hikmatullah dan Sukarman, 2014) dan Sumatera (Watanabe et al., 2013). Pengaruh tanah mineral terhadap gambut di lokasi studi cukup kuat pada jarak 100 400 meter dari tanah mineral ultrabasa ditunjukkan oleh kandungan $\mathrm{K}$ dapat dipertukarkan yang tinggi (Tabel 2; Tim Faperta IPB, 2012).

Kandungan $\mathrm{Mg}$ dapat dipertukarkan pada semua lapisan gambut dan satuan jarak dikategorikan tinggi (Tim Faperta IPB, 2009). Kandungan Mg tinggi pada contoh gambut yang diteliti bukan berasal dari bahan pembentuk tanah gambut, melainkan terbawa dari tanah mineral hasil pelapukan batuan ultrabasa berkadar $\mathrm{Mg}$ tinggi. Daerah studi merupakan bagian dari Formasi Matano (Parkinson, 1998) dan jalur Sabuk Ophiolite (Hall dan Wilson, 2000) 
yang sebagian besar tersusun atas batuan ultrabasa seperti lherzolit, harzburgit, peridotit, dunit, piroksenit dan gabbro (Kadarusman et al., 2004). Fu et al. (2014) melaporkan bahwa lapisan batuan induk (bedrock) di sekitar lokasi tergolong batuan ultrabasa yang mengandung $\mathrm{MgO}$ sebesar 359,700 ppm, $\mathrm{CaO}$ sebesar 14,900 ppm dan kandungan $\mathrm{K}_{2} \mathrm{O}$ sebesar $200 \mathrm{ppm}$. Pelapukan pada bahan induk tersebut membentuk tanah yang mengandung $\mathrm{Mg}$ tinggi namun rendah kandungan $\mathrm{Ca}$ dan $\mathrm{K}$.

Berdasarkan kriteria Tim Faperta IPB (2012), kandungan $\mathrm{Na}$ dalam gambut di lokasi penelitian tergolong tinggi. Seperti halnya unsur makro, kandungan $\mathrm{Na}$ dalam bahan organik sebagai bahan induk gambut tergolong rendah, begitu pula dengan kandungannya pada batuan ultrabasa (Fu et al., 2014). Berdasarkan Tabel 2, kandungan $\mathrm{Na}$ yang tinggi dan $\mathrm{Na}$ dapat dipertukarkan cenderung meningkat dengan semakin dalam gambut. Hal ini diduga sebagai akibat adanya kelarutan Na yang berasal dari tanah mineral di bawah gambut yang banyak dipengaruhi oleh lingkungan marin. Sementara itu, kandungan unsur tersebut menurun secaranyata dengan semakin jauh dari tanah mineral ultrabasa. Ketebalan gambut yang semakin besar dan semakin jauh jarak dari tanah mineral menyebabkan suplai hara Na baik dari tanah mineral ultrabasa dan tanah mineral di bawahnya semakin berkurang.

Ketimpangan antara kandungan $\mathrm{Mg}$ dan $\mathrm{Na}$ dengan $\mathrm{K}$ dan $\mathrm{Ca}$ dalam larutan tanah seperti yang disajikan pada Tabel 3 berdampak buruk bagi kondisi fisikokimia tanah mineral (Zhang dan Norton, 2002). Morrissey et al. (2014) menemukan bahwa peningkatan kadar $\mathrm{Mg}$ dan $\mathrm{Na}$ pada tanah memicu peningkatan mineralisasi bahan organik dan emisi karbon. Peningkatan $\mathrm{Mg}$ dan $\mathrm{Na}$ dalam gambut mempercepat hidrolisis lignin, suberin (Strehse et al., 2018), polipeptida, protein (Smith dan Hansen, 1998), selulosa, dan hemiselulosa (Sjöström, 2013) menjadi monomernya dan menghasilkan senyawa rekalsitran seperti bahan humat yang merupakan sumber utama muatan tanah gambut (Sollins et al., 1996).

Unsur $\mathrm{Mg}, \mathrm{K}$ dan $\mathrm{Ca}$ merupakan hara makro essensial (Hawkesford et al., 2012), sedangkan $\mathrm{Na}$ adalah hara benefisial (Broadley et al., 2012) bagi tanaman. Ion $\mathrm{Ca}$ mempunyai afinitas yang besar untuk teradsorbsi pada mucigel di kompleks jerapan akar dibandingkan $\mathrm{Na}, \mathrm{Mg}$ dan K (Amory dan Dufey, 1984). Namun, aksi massa Mg dan $\mathrm{Na}$ terlarut dalam konsentrasi tinggi dapat menghalangi penyerapan $\mathrm{Ca}$ dan $\mathrm{K}$ oleh akar. Implikasi dari disparitas yang besar antara kandungan $\mathrm{Mg}$ dan $\mathrm{Na}$ dibandingkan dengan $\mathrm{Ca}$ dan $\mathrm{K}$ dalam tanah dilaporkan banyak peneliti mengakibatkan terhambatnya pertumbuhan dan perkembangan serta penurunan ketahanan tanaman terhadap serangan penyakit (Ghafoor et al., 1992; Kopittke dan Menzies, 2005; Ngadze et al., 2014), hal ini diduga karena tanaman kekurangan $\mathrm{Ca}$ dan K. Secara khusus, hal yang sama juga menghambat pertumbuhan dan perkembangan beberapa spesies tanaman palmael Arecaceae seperti kurma (Alhammadi dan Edward, 2009) dan sawit (Firmansyah, 2018).

\section{Hubungan antara Kandungan $\mathrm{Fe}$, $\mathrm{Cu}$ dan $\mathrm{Zn}$ dengan Kedalaman Lapisan Gambut dan Jarak dari Tanah Mineral Ultrabasa}

Distribusi total dan dapat dipertukarkan unsur hara $\mathrm{Fe}, \mathrm{Cu}$, dan $\mathrm{Zn}$ di lokasi penelitian berdasarkan kedalaman gambut dan jarak dari tanah mineral ditampilkan pada Tabel 4. Kandungan $\mathrm{Fe}, \mathrm{Cu}$ dan $\mathrm{Zn}$ total dalam berada di bawah batas kritis logam berat dalam tanah (Balittanah, 2009).

Tabel 2. Kandungan hara makro K, Ca, Mg dan Na berdasarkan kedalaman lapisan gambut dan jarak dari tanah mineral ultrabasa

\begin{tabular}{|c|c|c|c|c|c|c|c|}
\hline \multirow{2}{*}{ Faktor } & \multicolumn{4}{|c|}{ Dapat dipertukarkan } & \multicolumn{3}{|c|}{ Total } \\
\hline & $\mathrm{K}$ & $\mathrm{Ca}$ & $\mathrm{Mg}$ & $\mathrm{Na}$ & $\mathrm{K}$ & $\mathrm{Ca}$ & $\mathrm{Mg}$ \\
\hline & \multicolumn{7}{|c|}{--------------------------------------------- $\mathrm{mg} \mathrm{kg}^{-1}$----------------------------------------- } \\
\hline \multicolumn{8}{|c|}{ Kedalaman $(\mathrm{cm})$} \\
\hline \multicolumn{8}{|c|}{ N kedalaman: 12} \\
\hline $0-30$ & $118.0 \mathrm{ab}$ & 245.04 & 645.61 & 242.2 & $148.8 \mathrm{a}$ & $474.95 \mathrm{a}$ & $1,243.21 \mathrm{a}$ \\
\hline $30-60$ & $98.8 \mathrm{~b}$ & 253.37 & 692.40 & 255.8 & $86.3 b$ & $292.88 b$ & $935.00 \mathrm{~b}$ \\
\hline $60-90$ & $193.3 \mathrm{a}$ & 233.69 & 866.65 & 265.1 & $95.5 b$ & $258.28 b$ & $1,046.71 \mathrm{ab}$ \\
\hline Uji F & $*$ & $\operatorname{tn}$ & tn & tn & $* *$ & $* *$ & $* *$ \\
\hline Uji t & tn & tn & tn & tn & tn & $*$ & $\operatorname{tn}$ \\
\hline \multicolumn{8}{|l|}{ Jarak (m) } \\
\hline \multicolumn{8}{|l|}{$\mathrm{N}$ jarak: 6} \\
\hline 100 & $145.5 b$ & $296.89 \mathrm{ab}$ & $574.34 b$ & $258.3 \mathrm{ab}$ & $168.8 \mathrm{a}$ & $430.93 \mathrm{ab}$ & $1,148.00 \mathrm{ab}$ \\
\hline 200 & $312.9 \mathrm{a}$ & $415.05 \mathrm{a}$ & $1,256.63 \mathrm{a}$ & $292.3 \mathrm{a}$ & $163.8 \mathrm{a}$ & $353.33 \mathrm{abc}$ & $1,019.50 \mathrm{ab}$ \\
\hline 300 & $155.5 \mathrm{ab}$ & $169.23 b$ & $664.68 \mathrm{ab}$ & $248.1 \mathrm{ab}$ & $153.8 \mathrm{a}$ & $293.31 b c$ & $1,163.33 \mathrm{ab}$ \\
\hline 400 & $145.5 b$ & $261.99 \mathrm{ab}$ & $765.20 \mathrm{ab}$ & $256.6 \mathrm{ab}$ & $73.8 b$ & $214.37 \mathrm{c}$ & $976.58 \mathrm{ab}$ \\
\hline 500 & $47.1 \mathrm{~b}$ & $158.04 \mathrm{~b}$ & $545.19 b$ & $234.6 b$ & $65.5 b$ & $485.03 \mathrm{a}$ & $843.33 b$ \\
\hline Uji F & $* *$ & $* *$ & $*$ & $* *$ & $* *$ & $* *$ & $* *$ \\
\hline Korelasi & -0.65 & -0.56 & -0.28 & -0.41 & -0.66 & -0.08 & 0.03 \\
\hline Uji t & $* *$ & $* *$ & tn & $*$ & $* *$ & tn & tn \\
\hline
\end{tabular}


Tabel 3. Korelasi antar hara (dapat dipertukarkan dan total) dalam gambut pada lokasi studi

\begin{tabular}{|c|c|c|c|c|c|c|c|c|}
\hline \multirow{2}{*}{\multicolumn{2}{|c|}{ Hara dalam gambut }} & \multicolumn{7}{|c|}{ Dapat dipertukarkan } \\
\hline & & $\mathrm{K}$ & $\mathrm{Ca}$ & $\mathrm{Mg}$ & $\mathrm{Na}$ & $\mathrm{Fe}$ & $\mathrm{Cu}$ & $\mathrm{Zn}$ \\
\hline \multirow{7}{*}{ Dapat dipertukarkan } & $\mathrm{K}$ & 1.00 & & & & & & \\
\hline & $\mathrm{Ca}$ & $0.66^{* *}$ & 1.00 & & & & & \\
\hline & $\mathrm{Mg}$ & $0.63 * *$ & $0.77 * *$ & 1.00 & & & & \\
\hline & $\mathrm{Na}$ & $0.56^{* *}$ & $0.49^{* *}$ & $0.47^{* *}$ & 1.00 & & & \\
\hline & $\mathrm{Fe}$ & $-0.50 * *$ & -0.22 & -0.23 & -0.33 & 1.00 & & \\
\hline & $\mathrm{Cu}$ & $-0.40 *$ & $-0.40 *$ & -0.19 & -0.16 & 0.29 & 1.00 & \\
\hline & $\mathrm{Zn}$ & -0.13 & -0.33 & 0.12 & 0.01 & 0.10 & $0.55 * *$ & 1.00 \\
\hline \multirow{6}{*}{ Total } & $\mathrm{K}$ & $0.51 * *$ & $0.38^{*}$ & 0.15 & 0.29 & $-0.43^{* *}$ & $-0.36^{*}$ & $-0.43 * *$ \\
\hline & $\mathrm{Ca}$ & -0.08 & -0.03 & -0.15 & -0.28 & 0.03 & -0.23 & 0.03 \\
\hline & $\mathrm{Mg}$ & -0.07 & -0.18 & -0.28 & -0.09 & -0.04 & 0.24 & -0.04 \\
\hline & $\mathrm{Fe}$ & 0.06 & 0.0 & 0.06 & -0.01 & $-0.42 *$ & -0.11 & -0.27 \\
\hline & $\mathrm{Cu}$ & 0.22 & 0.09 & 0.09 & 0.18 & $-0.66^{* *}$ & -0.18 & -0.28 \\
\hline & $\mathrm{Zn}$ & $0.47 *$ & 0.24 & 0.25 & 0.33 & $-0.60 * *$ & -0.19 & -0.17 \\
\hline
\end{tabular}

Keterangan: *signifikan pada selang kepercayaan 95\%; **signifikan pada selang kepercayaan $99 \%$

Tabel 4. Kandungan unsur mikro $\mathrm{Fe}, \mathrm{Cu}$ dan $\mathrm{Zn}$ berdasarkan kedalaman dan jarak dari tanah mineral ultrabasa

\begin{tabular}{|c|c|c|c|c|c|c|}
\hline \multirow{2}{*}{ Faktor } & \multicolumn{3}{|c|}{ Dapat dipertukarkan } & \multicolumn{3}{|c|}{ Total } \\
\hline & $\mathrm{Fe}$ & $\mathrm{Cu}$ & $\mathrm{Zn}$ & $\mathrm{Fe}$ & $\mathrm{Cu}$ & $\mathrm{Zn}$ \\
\hline & & . & ------ & 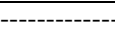 & 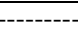 & \\
\hline \multicolumn{7}{|c|}{$\underline{\text { Kedalaman }(\mathrm{cm})}$} \\
\hline $0-30$ & 168.95 & 0.16 & 2.55 & $275.95 \mathrm{a}$ & 5.18 & 7.67 \\
\hline $30-60$ & 179.91 & 0.15 & 1.77 & $187.73 b$ & 4.17 & 3.25 \\
\hline $60-90$ & 229.97 & 2.28 & 2.29 & $150.98 b$ & 3.61 & 4.46 \\
\hline Uji F & tn & $\operatorname{tn}$ & tn & $* *$ & $\operatorname{tn}$ & $\operatorname{tn}$ \\
\hline Korelasi & 0,31 & 0,15 & 0,37 & $-0,43$ & $-0,21$ & $-0,31$ \\
\hline Uji t & tn & tn & $*$ & $* *$ & tn & tn \\
\hline \multicolumn{7}{|l|}{$\underline{\operatorname{Jarak}(\mathrm{m})}$} \\
\hline 100 & $204.75 \mathrm{ab}$ & 0.08 & 1.12 & 211.91 & 5.87 & $5.74 \mathrm{ab}$ \\
\hline 200 & $146.50 \mathrm{~b}$ & 0.05 & 1.30 & 203.61 & 4.02 & 7.12ab \\
\hline 300 & $88.80 \mathrm{~b}$ & 0.21 & 2.49 & 262.89 & 5.85 & $9.48 \mathrm{a}$ \\
\hline 400 & $118.46 b$ & 0.16 & 2.07 & 209.08 & 4.14 & $5.59 \mathrm{ab}$ \\
\hline 500 & $295.13 a$ & 1.77 & 4.20 & 161.13 & 2.77 & $1.18 \mathrm{~b}$ \\
\hline 600 & $304.02 \mathrm{a}$ & 2.90 & 2.04 & 180.69 & 3.28 & $1.64 \mathrm{ab}$ \\
\hline Uji F & $* *$ & tn & tn & tn & tn & $*$ \\
\hline Korelasi & 0,52 & 0,69 & 0,57 & $-0,18$ & $-0,36$ & $-0,38$ \\
\hline Uji t & $* *$ & $* *$ & $* *$ & tn & $*$ & $*$ \\
\hline
\end{tabular}

Keterangan: *berbeda nyata pada selang kepercayaan 95\%; **berbeda sangat nyata pada selang kepercayaan $95 \%$; tn: tidak berbeda nyata

Kandungan Fe yang tinggi dalam gambut bukan bersumber dari mineralisasi bahan organik, hal ini diduga oleh adanya akumulasi kedua unsur tersebut dari tanah mineral berbahan induk ultrabasa (Kadarusman et al., 2004; $\mathrm{Fu}$ et al., 2014) yang mengandung $\mathrm{Fe}$ total dalam kadar tinggi sebagai akibat dari proses erosi dan aliran permukaan. Hasil analisis total unsur $\mathrm{Fe}, \mathrm{Cu}$, dan $\mathrm{Zn}$ dalam tanah mineral berbahan induk ultrabasa disajikan pada Tabel 5.

Tabel 5. Hasil analisis total unsur mikro $\mathrm{Fe}, \mathrm{Mn}, \mathrm{Cu}$ dan $\mathrm{Zn}$ dalam tanah mineral ultrabasa

\begin{tabular}{lrrl}
\hline Unsur & \multicolumn{3}{c}{ Kadar $(\mathrm{ppm})$} \\
\hline Besi $(\mathrm{Fe})$ & 249,300 & \pm & 101,183 \\
Seng $(\mathrm{Zn})$ & 257 & \pm & 65 \\
Tembaga $(\mathrm{Cu})$ & 110 & \pm & 17 \\
\hline
\end{tabular}

Penurunan kandungan total hara mikro $\mathrm{Fe}, \mathrm{Cu}$ dan Zn dalam gambut dengan semakin jauh jarak dari tanah mineral pada Tabel 3 menunjukkan pengaruh tanah mineral yang semakin kecil. Ketersediaan unsur-unsur tersebut yang semakin meningkat sesuai peningkatan jarak diakibatkan oleh pengaruh $\mathrm{pH}$ yang semakin menurun (Tabel 1). Faktor yang sama juga menjadi penyebab ketersediaan tiga unsur tersebut yang cenderung mengalami kenaikan sesuai peningkatan kedalaman.

\section{SIMPULAN}

Nilai pH gambut menurun sangat nyata berdasarkan kedalaman lapisan gambut dan cenderung menurun dengan semakin jauh dari tanah mineral. Nilai KTK nyata meningkat sesuai peningkatan kedalaman lapisan gambut dan cenderung meningkat dengan semakin jauh jarak dari tanah mineral. Berdasarkan hasil pengukuran $\mathrm{Mg}$ dan $\mathrm{Fe}$, hara yang berasal dari tanah mineral mempengaruhi gambut hingga jarak $600 \mathrm{~m}$ dari batas gambut. Tanah gambut di lokasi mengandung $\mathrm{Mg}, \mathrm{Na}, \mathrm{Fe}$, $\mathrm{Mn}$, dan $\mathrm{Zn}$ dapat dipertukarkan dalam kadar tinggi dan $\mathrm{K}$ and $\mathrm{Ca}$ dapat dipertukarkan dalam kadar rendah. Hara $\mathrm{Cu}$ dapat dipertukarkan tergolong cukup pada semua kedalaman dan jarak, kecuali kedalaman 60-90 cm dan jarak 600 meter. Hara benefisial Na menunjukkan korelasi positif dengan kedalaman lapisan gambut yang mengindikasikan pengaruh marin pada tanah mineral bawah gambut. Disparitas yang besar antara $\mathrm{Mg}$ dengan kation lain dapat mengganggu penyerapan hara oleh akar tanaman dan memungkinkan pencucian $\mathrm{K}$ dan $\mathrm{Ca}$ keluar dari solum.

\section{DAFTAR PUSTAKA}

Alhammadi, M.S. and G.P. Edward. 2009. Effect of salinity on growth of twelve cultivars of the United Arab 
Emirates date palm. Commun. Soil Sci. Plan., 40: 2372-2388

Amory, D.E. and J.E. Dufey. 1984. Adsorption and exchange of $\mathrm{Ca}, \mathrm{Mg}$ and $\mathrm{K}$-ions on the root cell walls of clover and rye-grass. Plant. Soil., 80:181190

[Balittanah] Balai Penelitian Tanah. 2009. Analisis Kimia Tanah, Tanaman, Air, dan Pupuk. B.H. Prasetyo, D. Santoso, L.R. Widowati (Eds.). Balai Penelitian Tanah, Bogor. Pp. 211-213.

Broadley, M., P. Brown, I. Cakmak, J.F. Ma, Z. Rengel and F. Zhao. 2012. Beneficial Elements. In: Marschner P (Ed.), Marschner's Mineral Nutrition of Higher Plants. Elsevier, London. Pp. 249-257

Clymo, R.S. 1964. The origin of acidity in sphagnum bogs. Bryologist, 67(4): 427-431.

Fauque, G.D. 1995. Ecology of sulfate-reducing bacteria. In L.L. Barton (Ed.). Sulfate-Reducing Bacteria. Biotechnology Handbooks. $8^{\text {th }}$ Edition. Springer. Boston. p.217-241.

Firmansyah, E. 2018. Perubahan morfologis dan anatomis kelapa sawit pada rezim air dan salinitas berbeda. J. Agro., 5(1): 13-29.

Fu, W., J. Yang, M. Yang, B. Pang, X. Liu, H. Niu and X. Huang. 2014. Mineralogical and geochemical characteristics of a serpentinite-derived laterite profile from East Sulawesi, Indonesia: Implications for the lateritization process and $\mathrm{Ni}$ supergene enrichment in the tropical rainforest. $J$. Asian. Earth. Sci., 93: 74-88.

Ghafoor. A., M.I. Shahid, M. Saghir and G. Murtaza. 1992. Use of high-Mg brackish water on phosphogypsum and fym treated saline-sodic soil. II. Growth of wheat and rice. Pak. J. Agri. Sci., 29(3): 298-302.

Hall, R. and E.J. Wilson. 2000. Neogene suture in Eastern Indonesia. J. Asian Earth Sci., 18: 781-808.

Hawkesford. M., W. Horst, T. Kichey, H. Lambers, J. Schjoerring, I.S. Møller and P. White. 2012. Functions of Macronutrients. Beneficial Elements. In P. Marschner (Ed.), Marschner's Mineral Nutrition of Higher Plants. Elsevier, London. Pp. 135-189.

Hikmatullah and Sukarman. 2014. Physical and chemical properties of cultivated peat soils in four trial sites of ICCTF in Kalimantan and Sumatra, Indonesia. J. Trop. Soils, 19(3): 131-141.

Jenny, H. 1966. Pathways of ions from soil into root according to diffusion models. Plant. Soil, 25(2): 265-289.

Kadarusman, A., S. Miyashita, S. Maruyama, C.D. Parkinson and A. Ishikawa. 2004. Petrology, geochemistry and paleogeographic reconstruction of the East Sulawesi Ophiolite, Indonesia. Tectonophysics, 392: 55-83.
Kopittke, P.M. and N.W. Menzies. 2005. Mg induced Ca deficiency under alkaline conditions. Plant. Soil, 269: $245-250$.

Lindsay, W.L. and W.A. Norvell. 1978. Development of a DTPA soil test for zinc, iron, manganese, and copper. Soil. Sci. Soc. Am. J., 42: 421-428.

Lund, Z.F. 1970. The effect of calcium and its relation to several cations in soybean root growth. Soil Sci. Soc. Am. J., 34(3): 456.

Miller, R.O. 1998. Nitric-perchloric acid wet digestion in an open vessel. In YP Kalra (Eds.), Handbook of Reference Methods for Plant Analysis. CRC Press, Taylor \& Francis Group. New York. Pp. 57-62.

Miyajima, T., E. Wada, Y.T. Hanba and P. Vijarnsorn. 1997. Anaerobic mineralization of indigenous organic matters and methanogenesis in tropical wetland soils. Geochim. Cosmochim. Ac., 61(17): 3739-3751.

Morrissey, E.M., J.L. Gillespie, J.C. Morina and R.B. Franklin. 2014. Salinity affects microbial activity and soil organic matter content in tidal wetlands. Glob. Change Biol., 20(4): 1351-1362.

Mulyani, A., D. Nursyamsi dan D. Harnowo. 2016. Potensi dan Tantangan Pemanfaatan Lahan Suboptimal untuk Tanaman Aneka Kacang dan Umbi. In: A.A. Rahmianna, D. Harnowo, Sholihin, N. Nugrahaeni, A. Taufiq, Suharsono, E. Yusnawan, E. Ginting, F. Rozi, Hermanto (Eds.), Prosiding Seminar Hasil Penelitian Tanaman Aneka Kacang dan Umbi; 201625 Mei; Malang. Badan Penelitian dan Pengembangan Pertanian, Pusat Penelitian dan Pengembangan Tanaman Pangan, Bogor. Pp. 1630

Mulyani, A. dan M. Sarwani. 2013. Karakteristik dan potensi lahan sub optimal untuk pengembangan pertanian di Indonesia. Jurnal Sumberdaya Lahan, 7(1): 47-55.

Ngadze, E., T.A. Coutinho, D. Icishahayo and J.E. van der Waals. 2014. Effect of calcium soil amendments on phenolic compounds and soft rot resistance in potato tubers. Crop Protection, 62: 40-45.

Noor, M., Masganti, F. dan Agus. 2014. Pembentukan dan Karakteristik Gambut Tropika Indonesia. In F. Agus, M. Anda, A. Jamil, and Masganti (Eds.). Lahan Gambut Indonesia: Pembentukan, Karakteristik, dan Potensi Mendukung Ketahanan Pangan. Badan Penelitian dan Pengembangan Pertanian, Bogor. Pp. 7-32.

Page, S.E., R.A.J. Wüst, D. Weiss, J.O. Rieley, Ò.W. Shotyk and S.H. Limin. 2004. A record of Late Pleistocene and Holocene carbon accumulation and climate change from an equatorial peat bog (Kalimantan, Indonesia): implications for past, present and future carbon dynamics. $J$. Quaternary. Sci., 19(7): 625-635.

Parkinson, C. 1998. Emplacement of the East Sulawesi Ophiolite: evidence from subophiolite 
metamorphic rocks. J. Asian. Earth. Sci., 16(1): $13-28$.

Pester, M, K.H. Knorr, M.W. Friedrich, M. Wagner and A. Loy. 2012. Sulfate-reducing microorganisms in wetlands - fameless actors in carbon cycling and climate change. Front. Microbiol., 72(3): 1-19.

Ritung, S., E. Suryani, E. Yatno, Hikmatullah, K. Nugroho, Sukarman, R.E. Subandiono, M. Hikmat, C. Tafakresnanto, Suratman, H. Hidayat, D. Sudrajat, Ponidi, U. Suryana, W. Supriatna and A. Hartadi. 2019. Peta Lahan Gambut Indonesia Skala 1:50.000. December 2019 Edition. Balai Besar Penelitian dan Pengembangan Sumberdaya Lahan Pertanian, Bogor. 13 p.

Riwandi. 2001. Kajian stabilitas gambut tropika Indonesia berdasarkan analisis kehilangan karbon organik, sifat fisiko-kimia, dan komposisi bahan gambut [Tesis]. IPB, Bogor.

Sabiham, S. 2010. Properties of Indonesian Peat in relation to the chemistry of carbon emission. In: Z.-N. Cheng and F. Agus (Eds.), International Workshop on Evaluation and Sustainable Management of Soil Carbon Sequestration in Asian Countries. 2010 28-29 September; Bogor. Balai Penelitian Tanah, Bogor. Pp. 205-216.

Sabiham, S. 1988. Studies on peat in the coastal plains of Sumatra and Borneo. Part I: physiography and geomorphology of the coastal plains. Southeast Asian Studies, 27(4): 461-484.

Sabiham, S. and H. Furukawa. 1986. Problem soils in Southeast Asia: a study of floral composition of peat soil in the Lower Batang Hari River Basin of Jambi, Sumatra. Southeast Asian Studies, 24(2): 113-132.

Schollenberger, C.J. and R.H. Simon. 1945. Determination of exchange capacity and exchangeable bases in soil-ammonium acetate method. Soil. Sci., 59(1): $13-24$.

Sitorus, S.R.P., M. Mulyani dan D.R. Panuju. 2011. Konversi lahan pertanian dan keterkaitannya dengan kelas kemampuan lahan serta hirarki wilayah di Kabupaten Bandung Barat. J. Tanah. Lingk., 13(2): 49-57.
Sjöström, E. 2013. Wood Chemistry: Fundamentals and Applications. $2^{\text {nd }}$ Edition. Academic Press, San Diego.

Smith, R.M and D.E. Hansen. 1998. The $\mathrm{pH}$-rate profile for the hydrolysis of a peptide bond. J. Am. Chem. Soc., 120: 8910-8913.

Sollins, P., P. Homann and B.A. Caldwell. 1996. Stabilization and destabilization of soil organic matter: mechanisms and controls. Geoderma, 74: 65-105.

Spearman, C.E. 1904. The proof and measurement of association between two things. Am. J. Psychol., 15: 72-101.

Spearman, C.E. 1906. 'Footrule' for measuring correlation. Brit. J. Psychol., 2: 89-108.

Strehse, R., H. Bohne, Y. Amha and P. Leinweber. 2018. The influence of salt on dissolved organic matter from peat soils. Org. Geochem., 125: 270-276.

Tim Fakultas Pertanian. 2012. Evaluasi hasil pemupukan Pamafert di kebun kelapa sawit PT Gawi Bahandep Sawit Mekar. Sampit, Kalteng. Kerjasama Departemen Ilmu Tanah, Fakultas Pertanian IPB - PT Sri Rejeki Fertilizer, Bogor.

[USDA] United States Department of Agriculture. 2019. Oilseeds: World Markets and Trade. Foreign Agricultural Service, United States Department of Agriculture. Washington DC.

Watanabe, T., Y. Hasenaka, Suwondo, S. Sabiham and S. Funakawa. 2013. Mineral nutrient distributions in tropical peat soil of Riau, Indonesia with special reference to peat thickness. Jpn. Soc. Pedol., 57(2): 64-71.

Yonebayashi, K., J. Pechayapisit, P. Vijarnsorn, A.B. Zahari and K. Kyuma. 1994. Chemical alterations of tropical peat soils determined by Waksman's proximate analysis and properties of humic acids. Soil. Sci. Plant. Nutr., 40(3): 435-444.

Zhang, X.C. and L.D. Norton. 2002. Effect of exchangeable $\mathrm{Mg}$ on saturated hydrolic conductivity, disaggregation, and clay dispersion of disturbed soil. J. Hydrol., 260: 194-205. 